maintaining that the research enterprise would suffer if suddenly handed over to people without experience. To avoid a stalemate, the government turned for advice to the West.

The result was a large-scale study funded by a programme to help in the restructuring of Central European economies. The study, whose work was interrupted by the decision of the Czech Republic and Slovakia to go their separate ways, was conducted by the British consulting firm Segal Quince Wicksteed of Cambridge.

Some of the study's recommendations have already been implemented. Last month, for example, responsibility for science was transferred to the education ministry, which plans to establish a science unit to set national priorities. But the Ministry of Health will retain its own budget for medical research.

Efforts are also being made to create a system to make competitive grants. In 1991, part of the academy's budget was allocated on a competitive basis but the overall distribution of money did not change. The Ministry of Health introduced a system with a greater impact on funding decisions, and the Ministry of Education plans to use it as a model for an agency that would serve both universities and research institutes. The report advocates a 10-year evolution from a system giving nearly all the money directly to institutes to one allocating at least 85 per cent of its budget to individual projects.

Other recommendations will be implemented very soon. The report says that the first decade's grants should favour disadvantaged universities, giving them a chance to establish expertise in basic research, and it recommends that 20 per cent of the funds be set aside for collaborative work between universities and research institutes. But it argues against transferring the institutes to the higher education sector, saying the move would cause considerable disruption and might not foster such linkages. It wants centres of excellence dedicated to welldefined programmes of applied research, an idea in keeping with recommendations that the Czech Republic should focus on research encouraging long-term economic recovery.

The government is not expected to adopt all the recommendations. The report criticizes the government's decision to take a laissez-faire approach to technological development, reflecting a historical fear of authoritarian interference. An applied research centre in Prague (see left) is hoping to beat the odds. As usual, the major impediment to such an ambitious programme is money: since 1989 , research funding has fallen by 50 per cent in real terms. In times of such economic hardship, the will to maintain a relatively expensive research base must remain strong if the system is to flourish.

Alison Abbott

\title{
Congressional pork cramps NASA's ground-based projects
}

Washington. Managers of the US National Aeronautics and Space Administration (NASA)'s Earth science programme are struggling to find money for hundreds of ground-based research projects scheduled for 1993. Unless money can be transferred within accounts, managers of NASA's $\$ 150$ million Earth sciences research and analysis programme - which includes fundamental studies unconnected to specific spacecraft missions - may, in the words of one researcher, "have to tell some investigators not to go into the field this year". The programme provides grants averaging $\$ 100,000$ a year for ground- and aircraftbased investigations.

The shortage, which could amount to as much as $\$ 21$ million, results in part from a decision by Congress to spend $\$ 20$ million this year on an Earth science information centre in Michigan, the home state of retiring US Representative Bob Traxler, who headed the appropriations subcommittee for NASA. The Consortium for International Earth Science Information Network (CIESIN) was not requested by NASA, nor was it peer-reviewed, making it one of hundreds of so-called "porkbarrel" projects. Traxler retired at the end of last year after serving 18 years in Congress.

To make room for CIESIN, Congress deleted \$15 million from the "mission operations and data analysis" portion of NASA's proposed budget in Earth science. That would have cut funds for analysing data from the Upper Atmosphere Research
Satellite (UARS) launched in 1991 primarily to investigate ozone depletion in the upper atmosphere. Last month, however, NASA and Congress agreed instead to take the money out of the research and analysis budget, temporarily rescuing UARS.

The research and analysis programme includes much of NASA's fundamental work in verifying data from remote-sensing observations in space, including flights over Antarctica and the Arctic to measure atmospheric ozone loss, as well as expeditions to study global tropospheric chemistry, solid Earth geophysics and ocean processes. The money is also used for laboratory research to calibrate the results of such observations.

NASA plans to eliminate some investigations scheduled for 1993 if the money is not restored, says UARS project director Robert McNeal, rather than applying the budget cuts across the board. "I'd rather do some things well than squeeze everybody to the point where nothing can be done", he says.

Berrien Moore, director of the University of New Hampshire's Institute for the Study of Earth, Oceans and Space and an adviser to NASA's Earth Observing System (EOS) project, says that this year's shortage demonstrates that the agency does not have the necessary resources both to build the spacecraft it has planned - including the multibillion-dollar EOS - and to analyse the results from those missions. A budget that's already constrained, Moore says, "can't possibly tolerate these congressional add-ons".

Tony Reichhardt

\section{Chemical weapons treaty signed}

London. After 20 years of formal diplomatic negotiation - and many more of lobbying from the scientific community - an international treaty banning the development, production and use of chemical weapons is being signed in Paris this week.

The treaty, likely to come into effect early in 1995, will prohibit all work on toxic chemical agents, apart from what is necessary for purely defensive purposes. It will also require all signatory states that currently possess such weapons - primarily the United States and Russia - to destroy them over the next 15 years.

Formally known as the Chemical Weapons Convention, the treaty is welcomed by scientists who see the technology as epitomizing society's misuse of modern science. "I think it is an astonishing success to have solved all of the many problems involved in a manner agreeable to a large number of states", says Matthew Meselson, professor of molecular biology at Harvard University.

Effective policing of the treaty will depend largely on the operation of a new international agency, known as the Organization for the Prevention of Chemical Weapons (OPCW). Located in The Hague in the Netherlands, it is expected to take on a role comparable to that of the International Atomic Energy Agency in Vienna.

Several compromises have been necessary to reach final agreement. One involves the terms of 'challenge inspections', under which a signatory state can be required to demonstrate that fears of clandestine work on chemical weapons are unfounded. The United States - concerned that such challenges would be used to gather information from military facilities having little to do with chemicals production - has successfully argued that inspectors must wait for up to five days before entering a suspect site.

Similarly, the initial plan called for the destruction of existing stocks of chemical weapons within ten years. The United States and Russia are holding talks on appropriate technologies.
David Dickson 